\title{
Cardiopulmonary resuscitation training for schoolchildren and its effects on their prosocial behavior and knowledge: Mixed methods research design.
}

\section{Sanela Pivač ( $\square$ spivac@fzab.si )}

ABFHC https://orcid.org/0000-0003-2372-9497

\section{Primož Gradišek}

Univerza v Ljubljani Medicinska Fakulteta

\section{Brigita Skela-Savič}

Fakulteta za zdravstvo Angele Boskin

\section{Research article}

Keywords: skills, basic life support, public health concern, knowledge of schoolchildren

Posted Date: March 23rd, 2020

DOI: https://doi.org/10.21203/rs.2.14942/v2

License: (c) (1) This work is licensed under a Creative Commons Attribution 4.0 International License.

Read Full License

Version of Record: A version of this preprint was published at BMC Public Health on June 12th, 2020. See the published version at https://doi.org/10.1186/s12889-020-09072-y. 


\section{Abstract}

Background: The benefits of cardiopulmonary resuscitation training for schoolchildren are well known, but the appropriate age for introducing training is still being discussed. This is a very important issue, since out-of-hospital cardiac arrest is a major public health concern. The objective of this study is to investigate the effects of implemented cardiopulmonary resuscitation training on the knowledge and prosocial behavior of children in the last three grades of Slovenian elementary schools, and to identify the experience of training instructors. Methods: A mixed methods research design was employed, using a cohort study with testing before and after training, and focus groups. Research was conducted in 15 Slovenian public elementary schools offering cardiopulmonary resuscitation training. Focus groups included training instructors and developers. Data was collected with a structured questionnaire from April to June 2018 and analyzed using univariate and bivariate analyses. The three focus groups were convened in September and October 2018. Content analysis of the discussion transcriptions was conducted. The sample included 764 schoolchildren aged 12.5-14.5 years before cardiopulmonary resuscitation training and 566 schoolchildren after training. Three non-homogeneous focus groups included eight cardiopulmonary resuscitation instructors. Results: Significant progress in knowledge was noted after training implementation, with the greatest progress seen in the youngest age group (mean age 12.5). The greatest increase after the training was seen in confidence $(p=0.001)$, increase in helping behavior was moderate $(p=0.003)$, while the level of internal motivation prior to and after the training remained the same. Analysis of the focus groups yielded two themes: (a) the effects of cardiopulmonary resuscitation training on schoolchildren, and (b) the systemic responsibility of the school system and professional bodies. Conclusions: Significant progress in schoolchildren's cardiopulmonary resuscitation knowledge after training was established. Early introduction of training is recommended. Cardiopulmonary resuscitation knowledge influences the development of schoolchildren's prosocial behavior, as it raises awareness of the responsibility to help others and increases self-confidence to provide bystander cardiopulmonary resuscitation. We can conclude that early cardiopulmonary resuscitation training for children is crucial. It should be a mandatory part of school curricula in those countries where cardiopulmonary resuscitation is not yet mandatory.

\section{Background}

Out-of-hospital cardiac arrest (OHCA) is a major public health concern accounting for a substantial number of deaths worldwide. Each year, over 700,000 people in Europe and the USA suffer from OHCA. The survival to hospital discharge rate following OHCA remains low, ranging from 5 to $10 \%[1,2,3]$. Bystander cardiopulmonary resuscitation (CPR) is crucial for improving the chances of survival of sudden cardiac arrest patients and their neurological outcomes [4]. Bystander CPR rates differ widely across European countries [3]. It is estimated that at least $15 \%$ of the population would have to be trained in CPR for a significant increase of survival rates from cardiac arrest, but this cannot be achieved through voluntary trainings for the lay population alone; therefore, mandatory training of schoolchildren would be an important measure $[5,6]$. 
Awareness of the importance of CPR must be raised in early childhood education [7], as CPR training improves the safety culture in schools and shifts the responsibility from adults to children, which could result in long-term structural changes [6].

The introduction of CPR training in schools has been advocated by the World Health Organization [5]. In Scandinavia, teaching schoolchildren CPR has increased lay bystander CPR rates, resulting in higher survival rates after OHCA. Besides that, the productivity of society raises and consequently, the costs of health care decline [8]. Teaching the importance of OHCA recognition and CPR skills should begin early, as schoolchildren have greater motivation and learn faster than adults and also maintain learning abilities $[9,10]$. In some countries, CPR training for schoolchildren is already mandatory, in others it is being gradually introduced into curricula, with two hours of CPR training a year being recommended [11]. Nevertheless, the appropriate age to start CPR training remains controversial. If children learn CPR at a young age, they will not forget lifesaving skills, much like swimming or bike-riding skills [7]. In addition, children can serve as CPR multipliers as they may pass on the acquired awareness and CPR skills to family members and friends [12]. The advantages of early CPR teaching are reflected by helping behavior, increased confidence in the positive outcome of resuscitation, internal motivation to help people requiring assistance, and development of empathy $[13,14,15,16,17]$. Prosocial behavior refers to the voluntary activities of individuals aimed at helping others and doing good in return for internal satisfaction, it also denotes selfless concern for others based on empathy [17].

The effectiveness and outcome of CPR and automated external defibrillator (AED) training programs depend on the instructor's skills, knowledge and teaching tools (lecture, hands-only, instructional video, social networks) [16]. The school nurse who is the only healthcare professional at school has a pivotal role as an instructor, coordinator, and policy advocate for CPR and AED training [18].

Our research aimed to investigate the effect of implemented CPR training with the use of AED on schoolchildren's CPR knowledge and their prosocial behavior in the last three grades of elementary school in Slovenia. In addition, we were interested in the training instructors' experiences and opinions on the effects of implemented CPR training. We see the main contribution of this research in offering background for policy/decision-makers to involve CPR training as a mandatory part of school curricula. Research showed positive effects of training schoolchildren in CPR and so it is very important to involve the CPR training in the school curricula early enough. We found out that children of 12.5 years made the most progress in CPR knowledge.

\section{Methods}

\section{Design}

A mixed methods research design was employed. The aim was to achieve a more comprehensive approach to the investigated topic, measurements, and the analysis and interpretation of findings [19]. A cohort research method was conducted to obtain quantitative data and a focus groups research method was employed to obtain qualitative data. Both methods were combined in the interpretation stage. 


\section{Setting and participants}

\section{Cohort study}

The cohort study included Slovenian elementary schools (15) which offered CPR training in April and May 2018. Information on which schools and classes actually offered CPR training in that period were obtained from the preventive medicine and health promotion services (part of community health centers); they informed us in advance of the planned CPR trainings. CPR training is not mandatory in Slovenian school curricula. Schools make the decision themselves whether or not to include CPR training in their programs. For research purposes, instructors covered the same educational content and used the same teaching methods; they followed the national CPR program based on the European Resuscitation Council guidelines. Thus, the cohort study included all schoolchildren of the seventh, eighth, and ninth grades of 15 elementary schools which provided CPR training in the observed timeframe. Before CPR training with the use of AED was offered, 893 elementary school children were invited to participate in the study and 764 responded ( $85.6 \%$ response rate). One to two months after CPR training, only those schoolchildren who received the training were invited to participate $(n=764)$, and 566 responded $(74.1 \%$ response rate).

No significant differences were established in the sample structure prior to and after CPR training according to gender, age distribution, parents' education, and body mass index (BMI) of schoolchildren, which means that both samples were uniform. The gender distribution in the sample is fairly equal, with just under $50 \%$ of participants being boys and just over $50 \%$ being girls. Children in the final three grades of elementary school were aged 12-15 years. The mean age of seventh-graders, eighth-graders and ninthgraders was $12.5,13.5$ and 14.5 years, respectively. Distribution of schoolchildren among the three grades was equal prior to and after training.

\section{Focus group}

Out of 12 invited experts, eight participated in focus groups: instructors and CPR program developers working as nursing professionals in primary health care. Six participants were women, two were men, and their average length of service was 21.4 years $(S D=12.8)$. One participant held a master's degree in nursing, six were registered nurses, one was an emergency care assistant nurse. To start the debate, semistructured guiding questions were used.

\section{Instrument}

\section{Cohort research instrument}

Knowledge of CPR was measured using a structured questionnaire consisting of four sections with 27 nominal-level binary questions based on previous relevant research $[15,20,21,5,6]$. The sequence of items was designed according to the structure of the research problem. Images were used to increase schoolchildren's interest in filling out the questionnaire. Validity of the instrument was ensured by setting clear evaluation criteria and by making sure the questions were clearly formulated. Each correct answer was awarded one point; the point total was provided to compare results prior to and after CPR training. In 
the regression models, the independent variable 'Knowledge' was used with a score range of 0 to 15 . According to the final point count, respondents were categorized: excellent (15-13 points), very good (1211 points), good (10-9 points), satisfactory (8-7 points), and unsatisfactory (6 points or less). The level of prosocial behavior was assessed according to the level of knowledge. Respondents were divided into two groups: the first included those with excellent knowledge of CPR and the second those with less than excellent CPR knowledge.

Prosocial behavior was gauged with an ordinal scale of opinions consisting of 22 items. Items were designed based on a literature review $[6,15,17,21]$. The level of agreement was measured on a 5-point scale $(1=$ Strongly Disagree, 2 = Disagree, $3=$ Neither Agree Nor Disagree, $4=$ Agree, $5=$ Strongly Agree $)$. The reliability of items on prosocial behavior was good $(a=0.82)$. The demographic part of the questionnaire included questions on age, grade, month and year of birth, body weight, body height, and parental educational level.

\section{Pilot study}

Two pilot studies were carried out. The first one was conducted prior to CPR training and included 66 schoolchildren. For 26 items on prosocial behavior, Cronbach's alpha was .78. We excluded four items with low reliability. Additional instructions were provided for nominal-level binary questions used to test schoolchildren's CPR knowledge in order to clarify the question and the possible number of answers. With these improvements to the questionnaire, the second pilot study was carried out after CPR training. Cronbach's alpha for 22 items on prosocial behavior was .81, with 63 schoolchildren from the same cohort participating. Participants did not indicate any possible unintelligibility of items on CPR knowledge.

\section{Focus group instrument}

Semi-structured guiding questions were used for the focus groups and expanded as the discussion developed. Research reliability was ensured by following the prescribed methodology: the appropriate number of focus groups $(n=3)$ and the number of participants in each group $(n=8)$, which ensured data saturation in the third focus group.

\section{Data collection}

Cohort study data was collected twice from April to June 2018: prior to CPR training and one to two months following the training (May, June 2018).

Focus groups were convened after the implemented CPR training, in September and October 2018. The focus groups were led by a moderator employing a semi-structured questionnaire. All selected research participants received an invitation with a brief description of the research, general topics, and partial results of the quantitative research. The average duration of each focus group was 60 minutes. Discussions were recorded with participants' written consent. 


\section{Data analysis}

Data was analyzed using IBM software SPSS Statistics v. 22.0. Descriptive statistics was used to present the results of CPR knowledge test and the answers to the questions on prosocial behaviour, chi-square test was used to analyse the differences in the percentage of correct answers prior to and after CPR training. For establishing the differences in the level of knowledge and prosocial behaviour components prior to and after CPR training, we used a) t-test for comparing two samples, and b) one-way Anova for testing the differences between three groups (age groups) for a particular point in time. The common variables were defined using principal axis factoring (PAF) with orthogonal Varimax rotation. The level of statistical significance was set at $p \leq 0.05$.

For qualitative data, the method of thematic content analysis was employed. All recordings were transcribed verbatim and the texts were read several times. After coding units were identified, coding was conducted and categories and key themes were defined. Each focus group was ascribed a corresponding code. The nominal identity of a transcription was lost while the traceability of content was ensured.

\section{Results}

\section{CPR knowledge and prosocial behavior prior to and after CPR training}

Significant progress in knowledge was noted in most CPR-related procedures one or two months after the training. The greatest progress was in placing AED electrodes in the right positions, and in the chest compression rate and depth (all $p=0.001$ ). However, training did not increase the knowledge of other AED-related procedures like checking responsiveness and breathing before using AED (Table 1).

The mean level of the variable 'Knowledge' was $9.5(\mathrm{SD}=2.0)$ prior to and $11.5(\mathrm{SD}=2.0)$ after $\mathrm{CPR}$ training $(p=0.001)$.

Prior to the training, ninth-graders (average age of 14.5 years) had the highest level of knowledge ( $\mathrm{M}=$ $10.0 ; \mathrm{SD}=2.03)$, followed by seventh-graders (average age of 12.5 years) $(M=8.96 ; S D=2.19)$ and eighth-graders (average age of 13.5 years) $(M=9.37 ; S D=1.98)$ being behind by a point on average. The differences in CPR knowledge between age groups were significant $(p=0.001)$. After the training, the level of knowledge increased in seventh-graders $(M=11.62 ; S D=2.04)$, eighth-graders $(M=11.43 ; S D=$ $2.10)$, and ninth-graders $(M=11.52 ; S D=2.00)$. The increase in the level of knowledge for each age group when comparing the results prior to and after the training was significant $(p<0.05)$. After CPR training, all age groups had a comparable level of CPR knowledge. However, seventh-graders achieved the largest absolute difference in knowledge level (from 8.96 to 11.62 points on average).

The total means for items gauging prosocial behavior ranged between 3.39 and 4.49 prior to training and 3.96 and 4.61 after training. Factor analysis of these items revealed three constructs based on 15 opinions (loadings $<0.4$ ). The three constructs explained $32.0 \%$ of the measured phenomenon's variance with three variables: F1 - confidence $(a=0.711), F 2-$ helping behavior $(a=0.691)$, and F3 - internal 
motivation $(a=0.643)$. All the obtained factors extracted with the regression coefficient method were used in further statistical analysis (Table 2).

Levels of prosocial behavior prior to and after CPR training were measured. The greatest increase after the training was seen in confidence $(p=0.001)$, a moderate increase in helping behavior $(p=0.003)$, while the level of internal motivation prior to and after the training remained the same (Table 3 ). Schoolchildren with excellent CPR knowledge displayed a higher level of prosocial behavior in all areas ('Confidence' / $p$ $=0.001$; 'Helping Behavior' / $p=0.001$; 'Internal Motivation' / $p=0.049$ ) (Table 4).

\section{Instructors' perspectives on and experiences with CPR training}

Following text analysis, two main themes were developed: (a) Effects of CPR training on schoolchildren, and (b) Systemic responsibility of the school system and professional affiliations. Randomly selected examples of instructors' comments, positive and negative views on CPR training, and suggestions for school curriculum developers and responsible authorities are presented in Table 5.

\section{Discussion}

The effects of implementing CPR training with the use of AED on the knowledge of schoolchildren and their prosocial behavior was investigated. The study demonstrated an improvement in theoretical knowledge after CPR training. The provided training clearly increased the prevalence of schoolchildren's prosocial behavior. Our findings indicate that CPR training alone can raise not only children's level of CPR knowledge, but also prosocial behavior.

Specifically, children showed an improvement after training in theoretical knowledge on the question of which information has to be provided to paramedics in case a person is found unconscious and the correct position of an unconscious victim. Virtually all schoolchildren were familiar with the emergency telephone number in Slovenia, a result is comparable to the findings of previous studies [10], which underlies the positive effects of trainings. The greatest progress in 566 schoolchildren was seen in the knowledge of actions to be taken with an unconsciousness person, the placement of AED electrodes in correct positions, and the frequency and depth of chest compressions. Knowledge on the latter point after training was similar to findings reported from other studies [10]. Most of the schoolchildren in our research knew the right answer on how to use an AED; however, they were not as familiar with the fact that the emergency telephone number can also be dialed to receive instructions on its use. Schoolchildren are capable of determining whether the victim is conscious, calling for help, providing relevant information on the victim, and using AED [22]. Our research showed some progress on the correct CPR of a drowning victim, but the percentage of incorrect answers still remains high. Therefore, CPR instructions to schoolchildren should be simple and delivered uniformly for all causes of OHCA.

Our results revealed that the level of schoolchildren's theoretical knowledge on CPR was higher after CPR training and that the level of knowledge was retained one to two months after training. Similarly, other researchers found not only greater knowledge after CPR training, but also its retention [23, 20, 24]. Prior to 
CPR training, the level of CPR knowledge was highest in children with a mean age of 14.5 years, while children with mean ages of 12.5 and 13.5 years were less successful. After the implemented CPR training, the level of knowledge increased in all age groups. The greatest progress was seen in the youngest age group (mean age 12.5), because children in this group had to gain the most knowledge to be on par with their older peers. Therefore, we support early introduction of CPR training. Other authors have made similar recommendations $[25,22,16,24]$. What is more, younger schoolchildren have a greater capacity to learn the practical aspects of resuscitation compared to older children [24]. In Germany, research showed that the ability to implement practical CPR interventions among 10-year-olds was the same as among 13-year-olds [15]. However, schoolchildren aged 13 or more have greater theoretical knowledge $[15,24,26]$. Considering the assessed effectiveness of CPR training in schoolchildren, some advocate the introduction of CPR training between the ages of 10 and 11. In this age group, schoolchildren have the necessary intellectual capacity and, on average, an appropriate body weight to provide effective chest compressions $[15,16]$. Moreover, younger schoolchildren know how to place electrodes on the chest fast and effectively, while also ensuring safety beforehand [16, 24].

In the second part of our research, we compared the level of prosocial behavior prior to and after CPR training. After training, participants showed the most significant increase in confidence to help others, helping behavior somewhat increased, while the level of internal motivation remained the same prior to and after CPR training. In children of the final three grades of elementary school, increased CPR knowledge led to increased prosocial behavior. Similar conclusions were also reached by previous researchers $[13,23]$. As in our research findings, previous studies showed that CPR training boosts the confidence of schoolchildren [13]. Our findings showed that boys were more confident than girls.

CPR training for schoolchildren significantly increased their self-worth and moral responsibility towards themselves and the people around them [23]. CPR training reduced the fear of making a mistake in persons providing assistance to cardiac arrest victims, raised self-confidence, and promoted children's helping behavior [15]. Our research results also showed that, after CPR training, the percentages of those willing to help others increased. Similar studies stress the importance of early learning and implementation of training in intervals, because they believe that recurring trainings strengthen the prosocial and social behavior of schoolchildren [16]. Similarly, previous studies demonstrated that early learning of helping others makes schoolchildren better understand the importance of helping others and evolves their capacity for expressing empathy [27].

We were also interested in the instructors' experiences and opinions on the effects of the conducted CPR training. Analysis of the focus groups suggests training in CPR has to start at an early stage, with the content and teaching tools adjusted to the children's age.

The European Resuscitation Council Initiative and World Health Organization Statement endorse making CPR training a mandatory part of school curricula, as this would have a significant influence on the public health issue related to sudden cardiac arrest $[5,11,28]$. Focus group results showed obstacles for introducing CPR training in Slovenian schools, most notedly that CPR is at the moment an elective 
subject, not part of the mandatory school curricula. Furthermore, current instructors have been found to have different levels of knowledge and skills, highlighting the need for setting minimum criteria for certified CPR instructors. Closer cooperation with professional associations, which should set the minimum criteria for the implementation of trainings and for the potential instructors, is also required. According to the focus group members, these minimum criteria are: introduction of mandatory CPR training in school curricula, appropriate qualifications of instructors who must follow ERC recommendations on CPR, appropriate teaching methods employed by instructors, appropriate equipment and tools, the ability to adapt the content according to children's age, trainings in small groups, refreshment of knowledge both for instructors and schoolchildren. Support and guidance of instructors and other adults involved is crucial for the development of a responsible and emphatic approach towards teaching schoolchildren CPR [29].

Our results revealed the benefits and advantages of teaching schoolchildren CPR. It can be concluded that early CPR training for children is crucial and should be introduced as a mandatory part of school curricula in those countries where CPR is not yet mandatory.

\section{Limitations And Strengths}

A strength of the presented research is the sample size. The validity of conclusions could be increased if the methodology included an assessment of practical CPR skills. The study only investigated schoolchildren's theoretical knowledge. We are aware that testing only theoretical knowledge is not the only option, so we suggest future studies focus on the effects of practical training on CPR with the use of AED on schoolchildren's knowledge. The strength of correlations in the quantitative part of the research is low due to the proportions of factorial analysis variance explained, so these findings represent the basis for further improvements of the research instrument. The third focus group sample size was small since only two of the four invited participants responded by the given date. However, the third focus group was not cancelled due to ethical principles; it was implemented and in-depth conclusions were made.

\section{Conclusions}

The research findings provide the basis for decision-makers to introduce CPR training into the mandatory part of school curricula. We must also be aware that the endeavors for CPR topics to become a mandatory part of school programs can only be successful by employing a comprehensive, responsible approach and with the awareness of social responsibility. Nevertheless, it is very important to involve the CPR training into curricula. The youngest age group (12.5 years) made the most progress in CPR knowledge.

Results of the quantitative and qualitative research clearly demonstrate the positive effects of training schoolchildren in CPR. We found that the level of CPR knowledge correlated with prosocial behavior of 
schoolchildren, an important factor in their social development and the development of values, opinions, and beliefs. This research gives an important contribution to public health policy. It provides criteria for implementation of training schoolchildren in CPR, which is one of crucial factors of higher survival rate at cardiac arrest.

Our study findings are important for decision-makers and developers of school curricula who are responsible for making CPR training a mandatory part of school curricula. CPR training should be conducted continuously, for several years from the time schoolchildren are 12, and should be part of the mandatory school curricula. By doing so, we believe that CPR outcomes in cardiac arrest victims could significantly improve in the future. What is more, the necessary equipment, teaching materials, and teaching aids should be available to CPR training instructors, both for theoretical and practical training, as they are indispensable for efficient learning. This equipment should be provided by the institutions responsible for offering CPR training with the use of AED.

\section{Abbreviations}

CPR: cardiopulmonary resuscitation; OHCA: out-of-hospital cardiac arrest; AED: automated external defibrillator

\section{Declarations}

\section{Ethics approval and consent to participate}

Permission to conduct and implement the research was obtained from the Slovenian National Medical Ethics Committee on June 28, 2017 (0120-269/2017-4; KME 41/05/17).

Letters of consent on participants behalf were obtained from participating schools and community health centers, as well as from the parents of child respondents. Anonymity of research participants was ensured.

\section{Consent for publication}

Not Applicable.

\section{Availability of data and material}

The datasets used and/or analyzed during the current study are available from the corresponding author on reasonable request.

\section{Competing interests}

The authors declare that they have no competing interests.

\section{Funding}


This research did not receive any specific grant from funding agencies in the public, commercial, or notfor-profit sectors.

\section{Authors' contributions}

SP contributed to the conception and design of the study, theoretical introduction and discussion, acquisition of data, analysis and interpretation of data.

PG has made substantial contributions to the conception and design of the work; has aided in interpretation of data and has substantively revised the work. He also has approved the submitted version (and any substantially modified version).

BSS contributed to the conception and design of the study, development of instrument for data collection, definition of sample, interpretation of data, and discussion.

All authors drafted the manuscript and approved of the final version of the manuscript.

\section{Acknowledgements}

The authors would like to thank the schoolchildren who were willing to participate in the research, all CPR instructors, health education centers, the elementary schools which gave their consent for the research to be conducted, the teachers who helped coordinate the implementation of CPR trainings and the research, and the parents who gave their consent for the participation of their children in the research.

\section{References}

1. Berdowski J, Berg RA, Tijssen JG, Koster RW. Global incidences of out-of-hospital cardiac arrest and survival rates: systematic review of 67 prospective studies. Resuscitation. 2010;8:479-87; doi: 10.1016/j.resuscitation.2010.08.006.

2. Nishiyama C, Brown SP, May S, Iwami T, Koster RW, Beesems SG, et al. Apples to apples or apples to oranges? International variation in reporting of process and outcome of care for out-of-hospital cardiac arrest. Resuscitation. 2014;85:1599-609; doi: 10.1016/j.resuscitation.2014.06.031.

3. Gräsner JT, Lefering R, Koster RW, Masterson S, Böttiger BW, Herlitz J, et al. EuReCa ONE-27 Nations, ONE Europe, ONE Registry: A prospective one month analysis of out-of-hospital cardiac arrest outcomes in 27 countries in Europe. Resuscitation. 2016;105:188-95; doi: 10.1016/j.resuscitation.2016.06.004.

4. Geri G, Fahrenbruch C, Meischke H, Painter I, White L, Rea TD, et al. Effects of bystander CPR following out-of-hospital cardiac arrest on hospital costs and long-term survival. Resuscitation. 2017;115:129-34; doi: 10.1016/j.resuscitation.2017.04.016.

5. Böttiger BW, Van Aken H. Kids save lives-training school children in cardiopulmonary resuscitation worldwide is now endorsed by the World Health Organization (WHO). Resuscitation. 2015;94:A5-7; doi: 10.1016/j.resuscitation.2015.07.005. 
6. Calicchia S, Cangiano G, Capanna S, De Rosa M, Papaleo B. Teaching life-saving manoeuvres in primary school. Biomed Res Int. 2016;2016:2647235; http://dx.doi.org/10.1155/2016/2647235.

7. De Buck E, Van Remoortel H, Dieltjens T, Verstraetena H, Claryssea M, Moens O, et al. Evidence-based educational pathway for the integration of first aid training in school curricula. Resuscitation. 2015;94:8-22; doi: 10.1016/j.resuscitation.2015.06.008.

8. Wissenberg M, Lippert FK, Folke F, Weeke P, Hansen CM, Christensen EF, et al. Association of national initiatives to improve cardiac arrest management with rates of bystander intervention and patient survival after out-of-hospital cardiac arrest. JAMA. 2013;310:1377-84; doi: 10.1001/jama.2013.278483.

9. Markenson D, Ferguson J, Chameides L, Cassan P, Chung K, Epstein J, et al. Part 17: first aid: 2010 American Heart Association and American Red Cross Guidelines for First Aid. Circulation. 2010;122:934-46; doi: 10.1161/CIRCULATIONAHA.

10. Banfai B, Pek E, Pandur A, Csonka H, Betlehem J. The year of first aid': effectiveness of a 3-day first aid programme for 7-14-year-old primary schoolchildren. Emerg Med J. 2017;34:526-32; doi: 10.1136/emermed-2016-206284.

11. Böttiger BW, Semeraro F, Altemeyer KH, Breckwoldt J, Kreimeier U, Rücker G, et al. Kids save lives: school children education in resuscitation for Europe and the world. Eur J Anaesthesiol. 2017;34:7926; doi: 10.1097/EJA.0000000000000713.

12. Greif R, Lockey AS, Conaghan P, Lippert A, De Vries W, Monsieurs KG. European Resuscitation Council Guidelines for Resuscitation 2015. Section 10. Education and implementation of resuscitation. Resuscitation. 2015;95:288-301; doi: 10.1016/j.resuscitation.2015.07.032.

13. Maconochie I, Bingham B, Simpson S. Teaching children basic life support skills. BMJ. 2007;334:1174; doi: 10.1136/bmj.39218.422650.80.

14. Patsaki A, Pantazopoulos I, Dontas I, Passali C, Papadimitriou L, Xanthos T. Evaluation of Greek high school teachers' knowledge in basic life support, automated external defibrillation, and foreign body airway obstruction: implications for nursing interventions. J Emerg Nurs. 2012;38:176-8; doi: 10.1016/j.jen.2010.09.002.

15. Bohn A, Van Aken HK, Möllhoff T, Wienzek H, Kimmeyer P, Wild E, et al. Teaching resuscitation in schools: annual tuition by trained teachers is effective starting at age 10. A four-year prospective cohort study. Resuscitation. 2012;83:619-25; doi: 10.1016/j.resuscitation.2012.01.020.

16. Plant N, Taylor K. How best to teach CPR to schoolchildren: a systematic review. Resuscitation. 2013;84:415-21; doi: 10.1016/j.resuscitation.2012.12.008.

17. Decety J, Bartal IBA, Uzefovsky F, Knafo-Noam Empathy as a driver of prosocial behaviour: highly conserved neurobehavioural mechanisms across species. Philos Trans R Soc Lond B Biol Sci. 2016;371:20150077; doi: 10.1098/rstb.2015.0077.

18. Boudreaux S, Broussard L. Sudden cardiac arrest in schools: the role of the school nurse in AED program implementation. Issues Compr Pediatr Nurs. 2012;35:143-52; doi:

10.3109/01460862.2012.708214.

Page 12/19 
19. Polit DF, Beck CT. Essentials of nursing research: appraising evidence for nursing practice. $9^{\text {th }}$ Philadelphia: Wolters Kluwer; 2018.

20. Meissner TM, Kloppe C, Hanefeld C. Basic life support skills of high school students before and after cardiopulmonary resuscitation training: a longitudinal investigation. Scand J Trauma Resusc Emerg Med. 2012;20:1-7; doi: 10.1186/1757-7241-20-31.

21. Petrić J, Malički M, Marković D, Meštrović J. Students' and parents' attitudes toward basic life support training in primary schools. Croat Med J. 2013;54:376-80; doi: 10.3325/cmj.2013.54.376.

22. Bohn A, Lukas RP, Breckwoldt J, Böttiger BW, Van Aken H. 'Kids save lives': why school children should train in cardiopulmonary resuscitation. Curr Opin Crit Care. 2015;21:220-5; doi: 10.1097/MCC.0000000000000204.

23. Naqvi S1, Siddiqi R, Hussain SA, Batool H, Arshad H. School Children Training for Basic Life Support. J Coll Physicians Surg Pak. 2011;21:611-5; doi: 10.2011/JCPSP.611615.

24. Lukas RP, Van Aken H, Mölhoff T, Weber T, Rammert M, Wild E, et al. Kids save lives: a six-year longitudinal study of schoolchildren learning cardiopulmonary resuscitation: Who should do the teaching and will the effects last? Resuscitation. 2016;101:35-40; doi:

10.1016/j.resuscitation.2016.01.028.

25. Cave DM, Aufderheide TP, Beeson J, Ellison A, Gregory A, Hazinski MF, et al. Importance and implementation of training in cardiopulmonary resuscitation and automated external defibrillation in schools: a science advisory from the American Heart Association. Circulation. 2011;123:691-706; doi: 10.1161/CIR.0b013e31820b5328.

26. Wingen S, Schroeder DC, Ecker $H$, Steinhauser S, Altin S, Stock S, et al. Self-confidence and level of knowledge after cardiopulmonary resuscitation training in 14 to 18 -year-old schoolchildren: a randomised-interventional controlled study in secondary schools in Germany. Eur J Anaesthesiol. 2018;35:519-26; doi: 10.1097/EJA.0000000000000766.

27. Bollig G, Wahl HA, Svendsen MV. Primary school children are able to perform basic life-saving first aid measures. Resuscitation. 2009;80:689-92; doi: 10.1016/j.resuscitation.2009.03.012.

28. Link MS. CPR for kids: please try this at home. Journal Watch Cardiology. 2007;28:234-9.

29. Matchim Y, Kongsuwan W. Thai nursing students' experiences when attending real life situations involving cardiac life support: a Phenomenological study. Nurse Educ Today. 2015;35:1186-91; doi: 10.1016/j.nedt.2015.05.010.

\section{Tables}

Table 1 CPR knowledge of schoolchildren prior to and after CPR training 


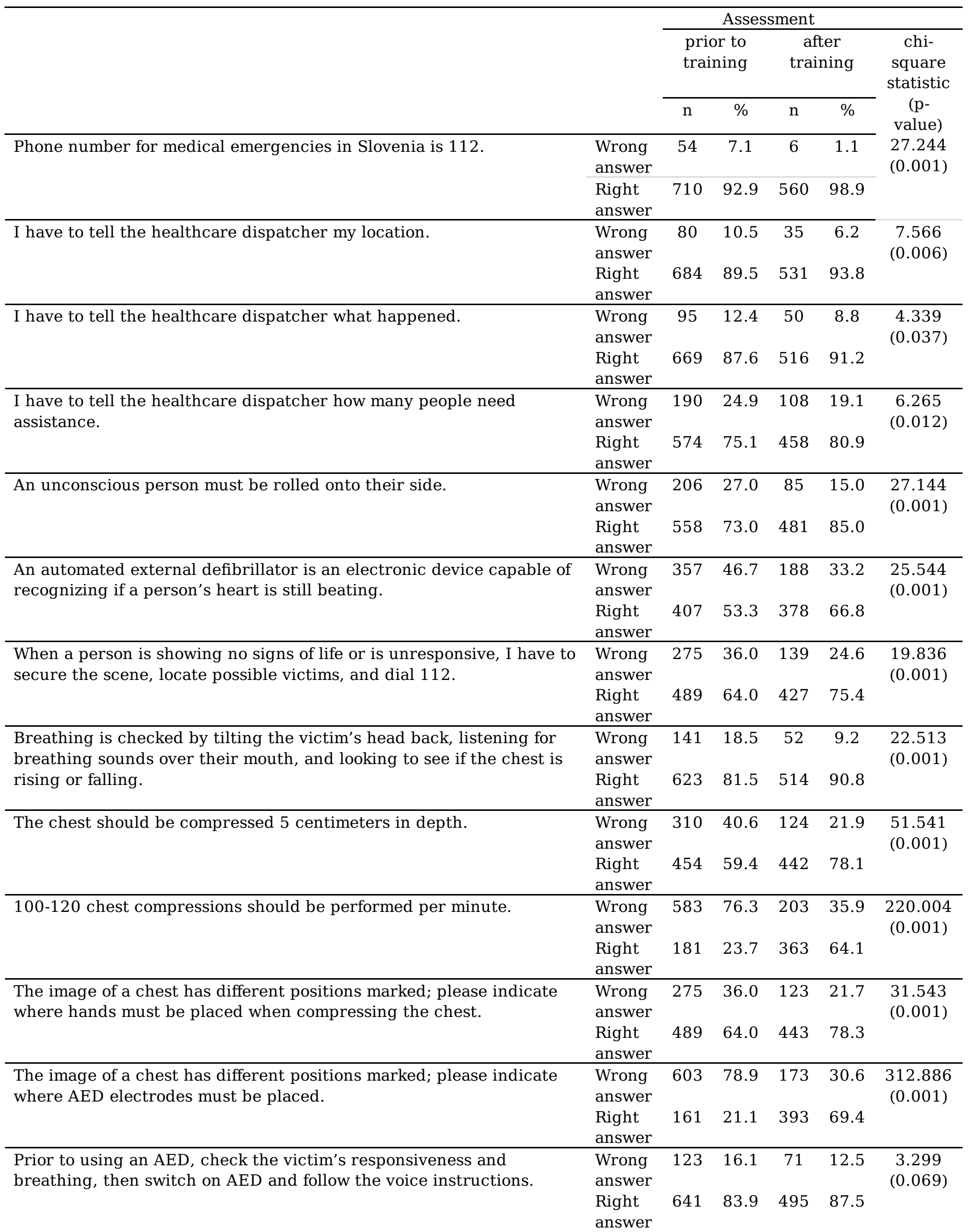




\begin{tabular}{|c|c|c|c|c|c|c|}
\hline \multirow[t]{2}{*}{$\begin{array}{l}\text { When using an AED, dial } 112 \text { and wait for instructions on how to use } \\
\text { the device. }\end{array}$} & $\begin{array}{l}\text { Wrong } \\
\text { answer }\end{array}$ & 492 & 64.4 & 354 & 62.5 & \multirow[t]{2}{*}{$\begin{array}{c}0.483 \\
(0.487)\end{array}$} \\
\hline & $\begin{array}{l}\text { Right } \\
\text { answer }\end{array}$ & 272 & 35.6 & 212 & 37.5 & \\
\hline \multirow{2}{*}{$\begin{array}{l}\text { Start resuscitating a drowning victim by checking their breathing, } \\
\text { give them five initial breaths, and then follow with chest } \\
\text { compressions. }\end{array}$} & $\begin{array}{l}\text { Wrong } \\
\text { answer }\end{array}$ & 438 & 57.3 & 254 & 44.9 & \multirow[t]{2}{*}{$\begin{array}{l}20.203 \\
(0.001)\end{array}$} \\
\hline & $\begin{array}{l}\text { Right } \\
\text { answer }\end{array}$ & 326 & 42.7 & 312 & 55.1 & \\
\hline
\end{tabular}

Legend: AED = automated external defibrillator; $\mathrm{n}=$ number; $\%=$ percentage; $\mathrm{p}=$ borderline statistical significance of 0.05 and less

Table 2 Descriptive statistics and factor analysis results on prosocial behavior 


\begin{tabular}{|c|c|c|c|c|c|c|c|c|c|}
\hline \multirow[b]{2}{*}{ Statements } & \multicolumn{3}{|c|}{ Prior to training } & \multicolumn{3}{|c|}{ After training } & \multirow[b]{2}{*}{ F1 } & \multirow[b]{2}{*}{ F2 } & \multirow[b]{2}{*}{ F3 } \\
\hline & $\mathrm{n}$ & M & SD & $\mathrm{n}$ & M & SD & & & \\
\hline $\begin{array}{l}\text { If I noticed a victim who was not moving or } \\
\text { showing signs of life, I would begin CPR } \\
\text { immediately, because I believe in myself.* }\end{array}$ & 759 & 3.43 & 1.09 & 565 & 3.99 & 0.78 & 0.666 & 0.115 & 0.157 \\
\hline $\begin{array}{l}\text { If I noticed a victim who was not moving or } \\
\text { showing signs of life, I would begin CPR } \\
\text { immediately, because I am not afraid of injuring } \\
\text { them.* }\end{array}$ & 762 & 3.39 & 1.18 & 565 & 3.96 & 0.84 & 0.658 & 0.110 & -0.035 \\
\hline $\begin{array}{l}\text { I would not dare to provide CPR before receiving } \\
\text { training.* }\end{array}$ & 761 & 3.42 & 1.23 & 565 & 3.92 & 0.94 & 0.566 & 0.076 & 0.120 \\
\hline $\begin{array}{l}\text { If someone falls down in front of me and shows no } \\
\text { signs of life, I would start CPR.* }\end{array}$ & 763 & 3.84 & 1.10 & 565 & 4.17 & 0.79 & 0.448 & 0.200 & 0.075 \\
\hline $\begin{array}{l}\text { I would dare to provide } \mathrm{CPR} \text { after receiving } \\
\text { training.* }\end{array}$ & 759 & 4.06 & 0.98 & 565 & 4.31 & 0.64 & 0.415 & 0.144 & 0.287 \\
\hline $\begin{array}{l}\text { I am willing to help others because I would also } \\
\text { expect help when in need. }\end{array}$ & 760 & 4.49 & 0.71 & 565 & 4.48 & 0.60 & 0.052 & 0.566 & 0.187 \\
\hline $\begin{array}{l}\text { If someone falls down in front of me, I would help } \\
\text { him.* }\end{array}$ & 761 & 4.49 & 0.77 & 565 & 4.61 & 0.55 & 0.146 & 0.462 & 0.136 \\
\hline I like to help others when they are in need.* & 762 & 4.29 & 0.79 & 565 & 4.44 & 0.56 & 0.132 & 0.462 & 0.372 \\
\hline $\begin{array}{l}\text { I help because I can recognize when a person is } \\
\text { not showing signs of life.* }\end{array}$ & 757 & 3.89 & 0.87 & 565 & 4.28 & 0.56 & 0.285 & 0.432 & 0.174 \\
\hline $\begin{array}{l}\text { If I noticed a group of people only observing a } \\
\text { victim not showing signs of life, I would start } \\
\text { providing help immediately. }\end{array}$ & 761 & 4.21 & 0.89 & 565 & 4.22 & 0.74 & 0.179 & 0.428 & 0.221 \\
\hline I notice when my friends and classmates need help. & 760 & 4.18 & 0.85 & 565 & 4.26 & 0.69 & 0.084 & 0.373 & 0.262 \\
\hline Helping others gives me satisfaction. & 759 & 4.27 & 0.82 & 565 & 4.32 & 0.71 & 0.124 & 0.192 & 0.528 \\
\hline $\begin{array}{l}\text { I feel for classmates and friends who are very ill or } \\
\text { were struck by misfortune. }\end{array}$ & 759 & 4.34 & 0.82 & 565 & 4.33 & 0.69 & 0.021 & 0.193 & 0.521 \\
\hline $\begin{array}{l}\text { I think one of the best things is being able to help } \\
\text { others. }\end{array}$ & 757 & 4.14 & 0.88 & 565 & 4.19 & 0.77 & 0.170 & 0.249 & 0.492 \\
\hline $\begin{array}{l}\text { When friends ask for my help, I don't hesitate and } \\
\text { help them right away. }\end{array}$ & 760 & 4.29 & 0.78 & 565 & 4.25 & 0.80 & 0.098 & 0.175 & 0.486 \\
\hline
\end{tabular}

Legend: CPR - cardiopulmonary resuscitation; $\mathrm{M}=$ mean on a 5-point scale (1 - Strongly Disagree / 5 - Strongly Agree), $\mathrm{n}=$ number of answers; SD = standard deviation, F1 = factor loading values 'Confidence' F2 = factor loading values 'Helping Behavior'; F3= factor loading values 'Internal Motivation'. *Differences in mean values between the first and second data collections are statistically significant $(\mathrm{p}<0.05)$ 
Table 3 A comparison of prosocial behavior components prior to and after CPR training

\begin{tabular}{|c|c|c|c|c|c|c|c|}
\hline & \multicolumn{6}{|c|}{ Before CPR trainingAfter CPR training } & \multirow{3}{*}{$\begin{array}{c}\text { g p-value } \\
\text { t-test } \\
\text { (before - after) }\end{array}$} \\
\hline & \multicolumn{3}{|c|}{$(\mathrm{n}=739)$} & \multicolumn{3}{|c|}{$(n=565)$} & \\
\hline & $\mathrm{n}$ & M & SD & $\mathrm{n}$ & M & $\mathrm{SD}$ & \\
\hline Confidence & 739 & -0.249 & 0.919 & 565 & 0.325 & 0.581 & $0.001 *$ \\
\hline Helping behavior & 739 & -0.051 & 0.846 & 565 & 0.067 & 0.586 & $0.003^{*}$ \\
\hline Internal motivatic & n 739 & 0.011 & 0.861 & 565 & -0.015 & 0.592 & 0.511 \\
\hline
\end{tabular}

Legend: $\mathrm{n}$ = number of schoolchildren, $\mathrm{M}=$ mean, $\mathrm{SD}=$ standard deviation (number of points obtained on the AED knowledge test from 0 to 15), *Progress for the component before VS after CPR training is statistically significant ( $p<$ $0.05)$.

Table 4 A comparison of prosocial behavior components between schoolchildren with excellent CPR knowledge and others

$\begin{array}{llll}\mathrm{n} & \mathrm{M} & \mathrm{SD} & \begin{array}{c}\text { t statistics } \\ (\mathrm{p} \text {-value })\end{array}\end{array}$

Grouping according to number of points achieved

\begin{tabular}{llcccc}
\hline Confidence* & Lower level of CPR knowledge & 1062 & -0.065 & 0.864 & -7.123 \\
\cline { 2 - 5 } & Excellent CPR knowledge & 242 & 0.287 & 0.649 & $(0.001)$ \\
\hline Helping behavior* & Lower level of CPR knowledge & 1062 & -0.042 & 0.766 & -4.820 \\
\cline { 2 - 5 } & Excellent CR knowledge & 242 & 0.183 & 0.625 & $(0.001)$ \\
\hline Internal motivation* & Lower level of CPR knowledge & 1062 & -0.017 & 0.780 & -1.972 \\
\cline { 2 - 5 } & Excellent CPR knowledge & 242 & 0.076 & 0.638 & $(0.049)$ \\
\hline
\end{tabular}

Legend: $\mathrm{n}=$ number; $\mathrm{M}=$ mean; $\mathrm{SD}=$ standard deviation; $\mathrm{t}$-test; $*$ Difference is statistically significant $(\mathrm{p}<0.05)$

Table 5 Suggestions from instructors 


\begin{tabular}{|c|c|c|c|c|}
\hline THEMES & SELECTED EXAMPLES OF COMMENTS & $\begin{array}{l}\text { POSITIVE } \\
\text { EFFECTS OF } \\
\text { CPR } \\
\text { TRAINING }\end{array}$ & $\begin{array}{l}\text { NEGATIVE } \\
\text { EFFECTS OF } \\
\text { CPR } \\
\text { TRAINING }\end{array}$ & $\begin{array}{l}\text { SUGGESTIONS } \\
\text { FOR SCHOOL } \\
\text { CURRICULUM } \\
\text { DEVELOPERS } \\
\text { AND } \\
\text { RESPONSIBLE } \\
\text { BODIES }\end{array}$ \\
\hline $\begin{array}{l}\text { Systemic } \\
\text { responsibility } \\
\text { of the school } \\
\text { system and } \\
\text { professional } \\
\text { affiliations }\end{array}$ & $\begin{array}{l}\text { (F3/U1): "They're mainly willing to help } \\
\text { others; they notice when a friend needs } \\
\text { help." } \\
\text { (F1/U1): "When a kid had an episode of } \\
\text { hypoglycemia, his classmate called for help". } \\
\text { (F2/U1): "After the training they're kind of } \\
\text { more confident, I think they're also happy } \\
\text { they can try chest compressions and talk to } \\
\text { each other about that, it's kind of an internal } \\
\text { satisfaction that I sense in the workshops." } \\
\text { (F1/U1): "It's definitely an investment in our } \\
\text { children, so to say, to teach them early } \\
\text { enough about resuscitation." } \\
\text { (F1/U3): "The point of the workshops is that } \\
\text { you're not scared of consequences in an } \\
\text { actual situation when someone falls down, so } \\
\text { that most kids aren't scared..." } \\
\text { (F2/U2): "I think it's important that topics } \\
\text { on resuscitation are included in the school } \\
\text { curriculum as mandatory, it has to be done } \\
\text { at the national level and everything } \\
\text { connected to it" and (F3/U1): "....sure, } \\
\text { topics have to be adapted for the age } \\
\text { group.....but even first-graders can bring an } \\
\text { AED, position the stickers and switch it on. } \\
\text { It's been proven that even little kids can } \\
\text { help that way. Even in daycare, like if they } \\
\text { watch a video of how compressions are } \\
\text { done." } \\
\text { (F1/U2): "...someone would have to assume } \\
\text { the overall management of the instructors } \\
\text { who would then be giving trainings, just like } \\
\text { the section does, that's how it should be. I } \\
\text { think it's in the best interest that trainings } \\
\text { are the same across Slovenia, not that we } \\
\text { have to get creative about how to } \\
\text { incorporate guidelines." }\end{array}$ & $\begin{array}{l}\text { Increased } \\
\text { prosocial } \\
\text { behavior. } \\
\text { Raising } \\
\text { awareness of } \\
\text { the } \\
\text { responsibility } \\
\text { to help others. } \\
\text { Positive effect } \\
\text { on emotional } \\
\text { development. } \\
\text { Less fear. } \\
\text { Increased } \\
\text { confidence. } \\
\text { Satisfaction and } \\
\text { independence } \\
\text { of } \\
\text { schoolchildren. } \\
\text { Long-term } \\
\text { memory of } \\
\text { storing } \\
\text { information on } \\
\text { resuscitation } \\
\text { procedures. }\end{array}$ & $\begin{array}{l}\text { Resuscitation } \\
\text { topics are } \\
\text { not } \\
\text { mandatory in } \\
\text { the } \\
\text { curriculum } \\
\text { of Slovenian } \\
\text { elementary } \\
\text { schools. } \\
\text { More } \\
\text { difficult } \\
\text { entry of } \\
\text { instructors } \\
\text { into the } \\
\text { school } \\
\text { setting. } \\
\text { Instructors } \\
\text { have } \\
\text { different } \\
\text { levels of } \\
\text { knowledge } \\
\text { on CPR } \\
\text { training. }\end{array}$ & $\begin{array}{l}\text { CPR topics would } \\
\text { have to become a } \\
\text { mandatory part of } \\
\text { school curricula } \\
\text { at the national } \\
\text { level. } \\
\text { CPR training has } \\
\text { to begin early, } \\
\text { topics are } \\
\text { adapted to the } \\
\text { age of } \\
\text { schoolchildren. } \\
\text { Trainings have to } \\
\text { be organized in } \\
\text { small groups. } \\
\text { Setting minimum } \\
\text { criteria for } \\
\text { instructors by } \\
\text { professional } \\
\text { interdisciplinary } \\
\text { societies: } \\
\text { required } \\
\text { certification, the } \\
\text { need to follow } \\
\text { ERC } \\
\text { recommendations } \\
\text { on CPR, } \\
\text { appropriate } \\
\text { teaching methods } \\
\text { employed by } \\
\text { instructors, } \\
\text { provision } \\
\text { appropriate } \\
\text { equipment and } \\
\text { tools for the } \\
\text { implementation of } \\
\text { CPR training, } \\
\text { CPR refreshment } \\
\text { courses, both for } \\
\text { instructors and } \\
\text { schoolchildren. }\end{array}$ \\
\hline
\end{tabular}

Legend: F1-3/U1-3: F1- 3= focus group number; U1-3: identification of focus group participant

\section{Supplementary Files}


This is a list of supplementary files associated with this preprint. Click to download.

- BMCQUESTIONNAIRE.pdf

- BMCFOCUSGROUPS.pdf 